\title{
KAJIAN KRITIS TERHADAP RATIO DECIDENDI HAKIM MENGABULKAN POLIGAMI DENGAN ALASAN SUAMI HIPERSEKSUAL DARI PERSPEKTIF KEADILAN GENDER
}

Fitri Hidayat ${ }^{1}$

${ }^{1}$ Fakultas Hukum, Ilmu Hukum, Universitas Brawijaya fitri.hidayat@,ub.ac.id

\begin{abstract}
ABSTRAK
Poligami atau beristri lebih dari seorang diizinkan oleh Undang-Undang dengan memenuhi berbagai syarat dan diizinkan oleh pengadilan. UndangUndang menyebutkan dalam pasal 4 ayat (2) alasannya yaitu: a. isteri tidak dapat menjalankan kewajibannya sebagai isteri; b. isteri mendapat cacat badan atau penyakit yang tidak dapat disembuhkan; c. isteri tidak dapat melahirkan keturunan. Empat penetapan poligami berikut yang ratio decidendinya menjadi perhatian, Putusan Nomor 0616/Pdt.G/2015/PA.Pwd, Putusan Nomor 905/Pdt.G/2012/PA.JB, Putusan Nomor 2593/Pdt.G/2017/PA.Jbg, Putusan Nomor 2670/Pdt.G/2012/PA.Lmg. Karena suami sebagai pemohonnya terbukti hiperseksual dan kemudian dikabulkan untuk poligami oleh hakim dengan pertimbangan hukumnya yaitu istri tidak dapat menjalankan kewajibannya sebagai seorang istri. Hiperseksual merupakan gangguan kejiwaan yang diidap seseorang. Jika ini yang digunakan sebagai dasar mengabulkan permohonan dan kemudian beban tanggung jawab dilimpahkan ke istri serta dilabeli tidak dapat menjalankan kewajiban sebagai seorang istri, maka ini tidak sesuai dengan prinsip keadilan gender. Keadilan gender yang dimaksud adalah keadilan gender dalam Islam. Pertimbangan hakim tersebut mengarah ke diskriminasi, seolah-olah apapun yang dilakukan perempuan jika tidak sesuai keinginan suami maka dilabeli tidak menjalankan kewajiban. Keadilan gender dalam Islam tidak mengenal diskriminasi.
\end{abstract}

ARTICLE INFO Kata Kunci:

Poligami; hiperseksual;

keadilan gender

Cite this paper:

Hidayat, F., 2020.

Kajian Kritis Terhadap Ratio Decidendi Hakim Mengabulkan Poligami Dengan Alasan Suami Hiperseksual Dari Perspektif Keadilan Gender. Widya Yuridika: Jurnal Hukum, $3(2)$.

\section{PENDAHULUAN}

Pada asasnya perkawinan adalah seorang suami mempunyai seorang istri dan begitu juga sebaliknya, ini yang disebut dengan monogami. Pada prinsipnya semua perkawinan berasas monogami, tetapi karena Indonesia ini plural, sehingga dalam Undang-Undang Perkawinannya masuk konsep hukum Islam, masuk konsep hukum adat, dan masih ada unsur dari KUH Perdata. Walaupun pada prinsipnya sudah tidak ada lagi penggolongan penduduk. Konsep hukum Islam sangat kental dalam Undang-undang Perkawinan, termasuk dalam pasal 3 yang mengatur tentang asas perkawinan. Pada pasal tersebut ditekankan bahwa pada prinsipnya perkawinan itu berasas monogami, tetapi karena dalam Islam dibolehkan mempnyai istri lebih dari seorang yang dikenal dengan 
bahasa awam poligami, maka pasal tersebut mengecualikan, sepanjang mendapat izin dari pengadilan. Tidak mungkin Undang-Undang Perkawinan tidak membolehkan poligami karena di dalam kitab suci umat Islam Alquran saja membolehkan sepanjang berlaku adil. Serta mayoritas penduduk atau warga negara Indonesia beragama Islam. Kenyataan tersebut tidak mungkin dipungkiri, sehingga harus dibuat pengecualian terhadap pasal asas perkawinan, yang kemudian disebut asas monogami relatif atau bisa disebut monogami terbuka.

Poligami atau beristri lebih dari seorang diizinkan oleh Undang-Undang dengan memenuhi berbagai syarat dan diizinkan oleh pengadilan. Karena syarat sah perkawinan adalah dilakukan menurut hukum agamanya dan dicatatkan pada lembaga pencatat perkawinan, maka jika ingin beristri lebih dari seorang dan dianggap sah oleh negara harus memenuhi syarat yang diminta Undang-Undang. Artinya jika ingin perkawinan poligami itu dianggap sah oleh negara, maka harus dilakukan sesuai hukum agamanya dan dicatatkan. Dengan kata lain jika poligami yang tidak dicatatkan maka dianggap perkawinan yang tidak sah oleh negara. Tetapi kecenderungan di masyarakat memilih untuk tidak dicatatkan karena syarat yang begitu berat dari Undang-Undang. Ternyata tidak semua laki-laki sanggup memenuhi persyaratan yang diminta oleh Undang-Undang.

Pasal 3 Undang-Undang Perkawinan menyatakan bahwa beristri lebih dari seorang harus dimohonkan ke pengadilan. Memang mengandung pilihan, jika perkawinan poligaminya ingin dianggap sah oleh negara maka ada syarat yang harus dipenuhi termasuk memohon ke pengadilan karena pengadilan yang memutus. Tapi jika merasa syarat yang harus dipenuhi dalam Undang-Undang berat maka memilih tetap melakukan perkawinan, tetapi tidak memohon ke pengadilan dan berakibat perkawinannya tidak dicatatkan dan akibat hukumnya menjadi perkawinan yang dianggap negara tidak sah. Jika negara melalui Undang-Undangnya mensyaratkan bahwa perkawinan lebih dari seorang harus dimohonkan ke pengadilan, maka hakim adalah gawang yang memutus permohonan itu. Bisa dikabulkan bisa juga tidak, tergantung aturan ditaati atau tidak juga tergantung kearifan hakim.

Syarat untuk bisa beristri lebih dari seorang, di dalam Undang-Undang ada yang disebut syarat alternatif dan ada yang disebut syarat kumulatif. Syarat alternatif ini yang harus dipenuhi tapi boleh tidak semuanya. Syarat ini ada pasal 4 Undang-Undang Perkawinan yaitu: ${ }^{1}$

(1) Dalam hal seorang suami akan beristeri lebih dari seorang,sebagaimana tersebut dalam Pasal 3 ayat (2) Undang-undang ini, maka ia wajib mengajukan permohonan kepada Pengadilan di daerah tempat tinggalnya.

(2) Pengadilan dimaksud dalam ayat (1) pasal ini hanya memberikan izin kepada seorang suami yang akan beristeri lebih dari seorang apabila:

a. isteri tidak dapat menjalankan kewajibannya sebagai isteri;

b. isteri mendapat cacat badan atau penyakit yang tidak dapat disembuhkan;

c. isteri tidak dapat melahirkan keturunan.

Pasal inilah yang disebut syarat alternatif dari poligami, sehingga pemohon harus mempunyai alasan yang tercantum dalam pasal tersebut tetapi boleh tidak semuanya, apakah alasan di ayat 2 huruf a istri tidak dapat menjalankan kewajibannya sebagai istri

${ }^{1}$ Pasal 4 Undang-Undang Nomor 1 Tahun 1974 tentang Perkawinan 
atau huruf $\mathrm{b}$ istri mendapat cacat badan atau penyakit yang tidak bisa disembuhkan atau huruf $\mathrm{c}$ istri tidak dapat melahirkan keturunan. Pemohon harus bisa mencantumkan alasan yang mana untuk punya dasar yang kuat untuk poligami. Jika memohon harus lewat pengadilan maka yang terpenting adalah bukti, pemohon harus bisa membuktikan bahwa istri sebelumnya memiliki alasan-alasan tersebut.

Kemudian yang selanjutnya harus dipenuhi oleh pemohon adalah syarat kumulatif yang mana pemohon tidak boleh meninggalkan salah satunya. Artinya syarat ini harus dipenuhi semua oleh pemohon poligami, diatur pada pasal 5 Undang-Undang Perkawinan: ${ }^{2}$

(1) Untuk dapat mengajukan permohonan kepada Pengadilan, sebagaimana dimaksud dalam Pasal 4 ayat (1) Undang-undang ini, harus dipenuhi syarat-syarat sebagai berikut:

a. adanya persetujuan dari isteri/isteri-isteri;

b. adanya kepastian bahwa suami mampu menjamin keperluan-keperluan hidup isteri isteri dan anak-anak mereka;

c. adanya jaminan bahwa suami akan berlaku adil terhadap isteri-isteri dan anak-anak mereka.

(2) Persetujuan yang dimaksud pada ayat (1) huruf a pasal ini tidak diperlukan bagi seorang suami apabila isteri/isteri-isterinya tidak mungkin dimintai persetujuannya dan tidak dapat menjadi pihak dalam perjanjian, atau apabila tidak ada kabar dari isterinya selama sekurang-kurangnya 2 (dua) tahun, atau karena sebab-sebab lainnya yang perlu mendapat penilaian dari Hakim Pengadilan.

Syarat-syarat inilah yang harus dipenuhi oleh pemohon poligami, pasal 5 terlihat sangat teknis tetapi harus dipenuhi semua dan ini yang dimaksud dengan syarat yang berat. Mutlak harus ada izin istri atau istri-istrinya dan harus persetujuan tertulis. Adanya kepastian bahwa suami mampu menjamin keperluan hidup seluruh keluarganya kelak. Sebetulnya ini sulit untuk diimplementasikan karena bagaimana parameternya. Tetapi hakim biasanya menggunakan slip gaji atau bukti penghasilan suami. Sehingga hakim membuktikannya dengan sesuatu yang bersifat materiil. Kemudian syarat yang terakhir adalah jaminan mampu berlaku adil, ini syarat tersulit menurut peneliti karena apa yang bisa membuktikan dapat berlaku adil sedangkan adil bagi setiap orang berbeda. Artinya parameter adil pun berbeda-beda. Inipun hakim biasanya hanya meminta surat pernyataan dapat berlaku adil dari suami. Syarat yang menurut peneliti sulit diimplementasikan.

Karena memang hukum poligami atau beristri lebih dari seorang adalah untuk yang beragama Islam, sehingga yang berwenang memutus adalah Pengadilan Agama. Seperti pada penetapan Pengadilan Agama di bawah ini:

\section{Putusan Nomor 0616/Pdt.G/2015/PA.Pwd ${ }^{3}$}

Pemohon mengajukan permohonan izin poligami karena alasan Pemohon memiliki dorongan seksual yang tinggi (hiperseks) sehingga isteri tidak maksimal saat melayani Pemohon, sebab hampir setiap hari Pemohon mengajak isteri untuk berhubungan badan. Hal ini menyebabkan isteri seringkali merasakan nyeri pada perut bagian bawah. Majelis Hakim pada pertimbangan hukumnya, berkesimpulan bahwa Termohon yaitu isteri Pemohon sudah tidak mampu melayani Pemohon.

2 Pasal 5 Undang-Undang Nomor 1 Tahun 1974 tentang Perkawinan

3 Putusan Nomor 0616/Pdt.G/2015/PA.Pwd. 
Pada ketentuan alasan permohonan izin poligami yang ditentukan oleh Pasal 4 ayat (2) huruf a UU Perkawinan yang memberikan kesempatan kepada suami untuk mengajukan permohonan izin poligami dengan alasan isteri tidak mampu memenuhi kewajibannya sebagai isteri, padahal pada alasan permohonan, pihak yang mengalami masalah adalah Pemohon atau suami karena mengalami hiperseks yang menyebabkan isteri mengalami rasa nyeri pada perut bagian bawah akibat secara terus-menerus berhubungan intim untuk menuruti keinginan Pemohon.

2. $\quad$ Putusan Nomor 905/Pdt.G/2012/PA.JB 4

Alasan Pemohon pada putusan ini mengajukan permohonan poligami adalah Termohon sebagai isteri tidak bisa melayani nafsu syahwat suami yang sangat besar, dalam hubungan suami isteri secara maksimal dan untuk menghindari perbuatan zina, padahal berdasarkan keterangan saksi pada persidangan, Pemohon telah menghamili calon isteri dan telah hamil empat bulan. Berdasarkan fakta persidangan, Hakim menyimpulkan Pemohon ingin menikah lagi karena Pemohon memiliki nafsu syahwat yang sangat besar (hiperseks) sehingga Termohon kurang mampu melayani hubungan intim suami isteri secara maksimal. Pemohonlah justru yang memiliki masalah yaitu mengalami penyimpangan seksual berupa hiperseks sehingga meskipun dilayani oleh isteri, Pemohon tetap merasa kurang puas dan maksimal sehingga menjalin hubungan dengan calon isteri hingga hamil 4 bulan.

3. Putusan Nomor 2593/Pdt.G/2017/PA.Jbg5

Pemohon memiliki kelebihan nafsu syahwat (hiperseks), untuk itu Pemohon mengajukan permohonan poligami. Termohon yaitu isteri tidak dapat melayani kebutuhan Pemohon dengan maksimal. Hakim menimbang bahwa dasar alasan Pemohon mengajukan permohonan poligami adalah ketidakmampuan isteri untuk melayani Pemohon sebagai suami dengan maksimal akibat Pemohon yang memiliki kelebihan nafsu syahwat (hiperseks) sehingga Pemohon khawatir akan melakukan perbuatan yang dilarang oleh agama, jika Pemohon tidak melakukan poligami. Alasan ini yang kemudian oleh Majelis Hakim dikabulkan dan memberi izin kepada Pemohon untuk menikah dengan calon isteri kedua Pemohon, padahal ketidakmampuan isteri disini diakibatkan oleh Pemohon sebagai suami yang mengalami hiperseksual, yang pada faktanya memang memiliki kelebihan dorongan syahwat (hiperseks).

4. Putusan Nomor 2670/Pdt.G/2012/PA.Lmg6

Alasan Pemohon mengajukan permohonan adalah Termohon sebagai isteri tidak dapat menjalankan kewajibannya sebagai isteri. Karena Pemohon memiliki naluri seksual yang tinggi di atas rata-rata pada umumnya (hiperseks), dan Pemohon telah terlanjur mencintai calon isterinya. Hakim pada pertimbangannya menyatakan Termohon kurang bisa menjalankan kewajiban sebagai isteri dalam hal hubungan suami isteri, karena Pemohon merupakan seorang pria yang memiliki naluri seksual yang tinggi di atas rata-rata pria pada umumnya. Termohon merasa keberatan jika harus selalu melayani keinginan seksual Pemohon, sehingga alasan tersebut membuat Pemohon merasa khawatir jika

\footnotetext{
${ }^{4}$ Putusan Nomor 905/Pdt.G/2012/PA/JB.

5 Putusan Nomor 2593/Pdt.G/2017/PA.Jbg.

6 Putusan Nomor 2670/Pdt.G/2012/PA/Lmg.
} 
melakukan zina yang dilarang oleh hukum Agama dan Negara. Pengajuan permohonan izin poligami dengan alasan ini dikabulkan oleh Hakim, yang kenyataannya bahwa pihak Pemohonlah sebagai suami yang mengalami hiperseks sehingga merasa tidak terpuaskan dalam melakukan hubungan suami isteri, sehingga membuat Termohon merasa tidak sanggup untuk selalu melayani keinginan seksual Pemohon yang begitu tinggi.

Pada penetapan pengadilan di atas dapat dilihat pemohon memiliki alasan yang sama yaitu pemohon atau suami hiperseksual yaitu keinginan yang tinggi akan hubungan seksual dan memohon untuk bisa beristri lebih dari seorang. Pada penetapan pengadilan diatas suami menyatakan bahwa istrinya tidak mampu memenuhi kewajibannya sebagai seorang istri karena kewalahan dalam melayani keinginan suami. Inilah fokus penelitian ini, setelah sebelumnya ada penelitian yang membahas tentang kesesuaian alasan hiperseksual masuk dalam rumusan pasal 4 ayat 2 huruf a Undang-Undang Perkawinan yaitu istri tidak dapat menjalankan kewajibannya sebagi istri. Penelitian terdahulu tersebut menyimpulkan bahwa hiperseksual tidak sesuai dengan rumusan pasal 4 ayat 2 huruf a karena yang dimaksud tidak dapat memenuhi kewajiban sebagai istri itu adalah jika istri sengaja atau lalai untuk tidak melayani suaminya. ${ }^{7}$ Pada penetapan di atas Hakim mengabulkan permohonan pemohon karena didasarkan pada pasal 4 ayat (2) huruf a yaitu istri tidak dapat menjalankan kewajibannya sebagi seorang istri. Padahal hiperseksual ada dalam diri laki-laki yang mana kelebihan nafsu untuk melakukan hubungan seksual. Tapi kemudian hukum melimpahkan pada tanggung jawab itu pada perempuan. Kemudian hakim memberikan poligami sebagai solusinya.

Dalam Alquran terdapat surat yang isinya khusus mengenai perempuan yaitu surat An-nisa'. Islam memandang laki-laki dan perempuan sama saja, sama-sama khalifah di bumi yang membedakan hanya ketaqwaan pada Allah. Dapat dilihat pada surat Al-Hujurat ayat 13: "Hai manusia sesungguhnya kami menciptakan kamu dari seorang laki-laki dan seorang perempuan dan menjadikan kamu berbangsa-bangsa dan bersuku-suku supaya kamu saling kenal-mengenal. Sesungguhnya orang yang paling mulia diantara kamu di sisi Allah adalah orang yang paling bertakwa diantara kamu." Hanya Allah melebihkan sedikit kaum laki-laki dari kaum perempuan, karena laki-laki adalah pemimpin dan pelindung bagi perempuan. Allah melebihkan sedikit disini adalah masalah tanggung jawab terhadap perempuan. Seperti pada surat An-Nisa'ayat 34: "Kaum laki-laki itu adalah pemimpin bagi kaum wanita, oleh karena Allah telah melebihkan sebagian mereka (lakilaki) atas sebagian yang lain (wanita) dan karena mereka (laki-laki) telah menafkahkan sebagian dari harta mereka". Karena hal-hal tersebut diatas peneliti ingin mengkaji Ratio decidendi hakim dari sudut pandang keadilan gender. Khususnya apakah ada kesesuaian ratio decidendi hakim tersebut dengan keadilan gender dalam Islam. Hiperseksual pada putusan pengadilan di atas adalah masalah pada suami, tetapi seakan istri yang menerima akibatnya dari penetapan pengadilan di atas.

Penelitian yang dilakukan ini adalah penelitian hukum yaitu penelitian yang dilakukan dengan cara mengkaji peraturan perundang-undangan yang berlaku atau diterapkan pada suatu permasalahan hukum tertentu. Penelitian ini sering disebut dengan penelitian doktrinal, yaitu penelitian yang obyek kajiannya adalah dokumen

7 Sulistyarini, Kesesuaian Alasan Suami hiperseksual Dalam Permohonan Izin Poligami Dengan Pasal 4 ayat (2) huruf a Undang-Undang Nomor 1 Tahun 1974 tentang Perkawinan, Skripsi , Fakultas Hukum Universitas Brawijaya, hlm 65 
peraturan perundang-undangan dan bahan pustaka. ${ }^{8}$ Pada penelitian ini, peneliti mengkaji bagaimana ratio decidendi hakim dalam putusan yang mengabulkan poligami dengan alasan hiperseksual dilihat dari perspektif keadilan gender.

\section{Pendekatan Penelitian}

Sehubungan dengan jenis penelitian yang digunakan, yaitu penelitian doktrinal, maka pendekatan yang digunakan adalah pendekatan perundang-undangan (statute approach), yaitu pendekatan yang dilakukan dengan menelaah semua undang-undang dan regulasi yang bersangkut paut dengan isu hukum yang sedang ditangani. ${ }^{9}$ Dalam hal ini aturan mengenai alasan permohonan poligami yang dikabulkan oleh hakim.

2. Bahan hukum

1) Bahan hukum primer yaitu bahan hukum yang bersifat autoritatif artinya mempunyai otoritas. ${ }^{10} \mathrm{Di}$ dalam penelitian ini peneliti mengkaji aturan mengenai batalnya perkawinan:

a. Putusan Nomor 0616/Pdt.G/2015/PA.Pwd

b. Putusan Nomor 905/Pdt.G/2012/PA.JB

c. Putusan Nomor 2593/Pdt.G/2017/PA.Jbg

d. Putusan Nomor 2670/Pdt.G/2012/PA.Lmg

e. Pasal 4 dan 5 Undang-Undang Nomor 1 Tahun 1974 tentang Perkawinan.

f. Pasal 55-59 Instruksi Presiden Nomor 1 Tahun 1991 tentang Penyebarluasan Kompilasi Hukum Islam.

2) Bahan hukum sekunder yaitu semua publikasi tentang hukum yang bukan merupakan dokumen-dokumen resmi ${ }^{11}$, yang meliputi:

a. Buku-buku literatur atau bacaan yang menjelaskan mengenai hukum perkawinan khususnya mengenai perceraian, masa iddah, serta larangan perkawinan.

b. Hasil-hasil penelitian mengenai hukum perkawinan khususnya mengenai perceraian, masa iddah serta larangan perkawinan.

3) Bahan Hukum Tersier, merupakan bahan hukum penunjang, meliputi:

a. Kamus Bahasa Indonesia

b. Kamus Hukum

3. Teknik Analisis Bahan Hukum

Penelitian ini dianalisis dengan menggunakan teknik interpretasi yaitu:

1) Teknik interpretasi gramatikal yaitu berdasarkan kata-kata yang digunakan dalam pasal 4-5 Undang-Undang Perkawinan dan pasal 55-59 Kompilasi Hukum Islam.

2) Teknik interpretasi sistematis yaitu berdasarkan susunan pasal satu dengan pasal yang lain, peraturan perundang-undangan satu dengan peraturan perundang-undangan yang lain. Pada penelitian ini adalah Undang-Undang Perkawinan, Peraturan Pemerintah serta Kompilasi Hukum Islam.

\footnotetext{
8 Soejono dan H. Abdurahman, Metode Penelitian Hukum, Jakarta, Rineka Cipta, 2003, hlm. 56

${ }_{9}^{9}$ Peter Mahmud Marzuki, Penelitian Hukum, Jakarta, Kencana Prenada Group, 2005, hlm. 93

${ }^{10}$ Ibid, hlm. 141

${ }^{11} \mathrm{Ibid}$
} 
3) Teknik interpretasi ekstensif yaitu menafsirkan dengan memperuas makna peraturan perundang-undangan.

4) Teknik interpretasi teleologis yaitu menafsirkan peraturan perundangundangan sesuai dengan perkembangan serta kebutuhan masyarakat saat ini. Pada penelitian ini yaitu menafsirkan poligami itu sendiri, alasan hiperseksual, syarat poligami, juga keadilan.

\section{Definisi Konseptual}

1) Poligami yang dimaksud pada penelitian ini adalah suami yang beristri lebih dari seorang.

2) Permohonan poligami pada penelitian ini dibatasi permohonan poligami dengan alasan suami hiperseksual.

Perspektif keadilan gender yang dimaksud pada penelitian ini merupakan perspektif dalam Islam terhadap posisi perempuan dalam hukum serta keadilan terhadap perempuan dalam hal poligami.

\section{HASIL DAN PEMBAHASAN \\ Ratio Decidendi Hakim Pada Putusan Yang Mengabulkan Permohonan Poligami Dengan Alasan Hiperseksual}

Poligami atau beristri lebih dari seorang memang diperbolehkan dalam UndangUndang Perkawinan di Indonesia, dengan dasar dalam agama Islam juga diperbolehkan. Bahkan terdapat ayat tentang poligami ini dalam Alquran. Walaupun sesungguhnya praktek poligami sudah dikenal sejak sebelum diturunkannya Alquran, tidak hanya Arab tetapi juga bangsa-bangsa Barat. Justru setelah Alloh menurunkan ayat bolehnya beristri lebih dari seorang dengan pembatasan jumlah istri, poligami menjadi bermartabat. Jika Allah SWT saja membolehkan, artinya ini hukum Tuhan, maka tidak mungkin UndangUndang melarang. Hanya Undang-Undang memberikan syarat-syarat bagi suami yang ingin poligami, supaya lebih tertib dan tentu saja memberikan perlindungan hukum. Syarat inilah yang menjadi kunci poligami itu dikabulkan atau tidak oleh hakim.

Undang-Undang telah memberikan pakem terkait alasan poligami, hanya dikaitkan dengan tiga hal: istri tidak menjalankan kewajibannya sebagai seorang istri, istri mendapat cacat badan sehingga tidak mampu menjalanan kewajibannya sebagai seorang istri, dan istri tidak dapat melahirkan keturunan. Sempit sekali hanya tiga hal ini, tentu bertujuan untuk memberikan perlindungan hukum bagi istri. Walaupun di sisi lain ada hal yang menyudutkan istri. Namun pada kenyataannya hampir semua permohonan poligami dengan berbagai alasan, bahkan yang tidak terkait dengan tiga hal tersebut. Seperti pada empat putusan Pengadilan Agama ini Putusan Nomor 0616/Pdt.G/2015/PA.Pwd, Putusan Nomor 905/Pdt.G/2012/PA.JB, Putusan Nomor 2593/Pdt.G/2017/PA.Jbg, Putusan Nomor 2670/Pdt.G/2012/PA.Lmg. Ada kesamaan alasan serta ratio decidendi hakim dalam empat putusan tersebut, yaitu alasan suami hiperseksual dan hakim mengabulkan permohonan poligami. Ratio decidendi hakim adalah istri tidak dapat menjalankan kewajibannya sebagai seorang istri. Karena syarat yang diberikan Undang-Undang terbatas pada tiga hal seperti yang disebut diatas, maka hakim memasukkan alasan suami hiperseksual sebagai bagian dari pasal 4 huruf a Undang-Undang Perkawinan, yaitu istri tidak dapat menjalankan kewajibannya sebagai seorang istri.

\section{Kajian Mengenai Hiperseksual}

Hiperseksual adalah salah satu kondisi kelainan dalam berhubungan seksual. Hal ini masih menjadi perdebatan apakah ini tergolong penyakit atau bukan. Walaupun 
diperdebatkan, bukan berarti hal ini tidak ada. Hiperseksual nyata adanya dialami seseorang. Kasus hiperseksual rata-rata 2-6 \%, dan paling banyak dialami laki-laki, namun tidak tertutup kemungkinan perempuan juga mengalami. ${ }^{12}$ Hiperseksual adalah suatu keadaan dimana seseorang mempunyai dorongan keinginan melakukan hubungan seksual yang sangat kuat melebihi kondisi normal, baik secara intensitas maupun perilaku. Hiperseksual di kategorikan sebagai gangguan, karena di luar kondisi normal. Bisa dikatakan kondisi abnormal. Hiperseksual dapat dikategorikan sebagai compulsive behavior disorder, yaitu merupakan gangguan pada pikiran yang tidak dapat dikendalikan untuk melakukan sesuatu berulang-ulang atau terus menerus. Juga dapat dikategorikan sebagai sexual impulsivity, dimana impulsif merupakan tindakan tiba-tiba mengikuti kata hati dan sangat mungkin perilaku berubah seketika. Selain itu hiperseksual juga dikategorikan sebagai sexual addiction, dapat diartikan sebagai kecanduan terhadap hubungan seksual.13

Hiperseksual memang bukan penyakit secara fisik, tetapi termasuk penyakit mental atau gangguan mental, dalam istilah asing disebut mental illness. Gangguan mental inilah yang bisa mempengaruhi suasana hati, pikiran atau perilaku seseorang. Ganguan mental ini jenisnya bermacam-macam, yaitu: ${ }^{14}$
a. Gangguan Kecemasan
b. Gangguan suasana hati
c. Gangguan kepribadian
d. Obsessive-compulsive disorder
e. Gangguan psikotik
f. Gangguan makan
g. Kontrol impuls dan gangguan kecanduan
h. Post-traumatic stress disorder (PTSD)

Hiperseksual termasuk gangguan mental yaitu jenis gangguan kontrol impuls atau kecanduan. Termasuk jenis tersebut karena yang bersangkutan tidak dapat mengontrol apa yang seharusnya bisa dikontrol. Yang bersangkutan menjadi obyek dari gangguan tersebut. Tidak dapat dipungkiri bahwa hiperseksual merupakan sesuatu yang menyimpang, sehingga harus dikembalikan ke kondisi normal. Artinya jika secara ilmiah ini dikategorikan sebagai gangguan kejiwaan, semestinya bisa disembuhkan dan perlu disembuhkan. Sehingga orang yang mengidap gangguan kejiwaan khususnya berupa hiperseksual harus dicarikan solusi untuk menyembuhkan gangguan tersebut.

Dalam konteks hubungannya dengan empat putusan di atas, antara syarat yang diberikan Undang-Undang Perkawinan, alasan permohonan, ratio decidendi hakim serta putusan dikabulkan, menjadi tidak bisa ditarik benang merahnya. Jika diuraikan satu persatu, syarat poligami dari undang-Undang Perkawinan adalah tiga alasan tersebut di atas, dan memang titik beratnya pada istri. Logika Undang-Undang, seorang suami memohon poligami karena ada sesuatu pada istri, jika tidak maka tidak perlu poligami. Pada empat putusan tersebut, suami memohon poligami karena dirinya sendiri hiperseksual, artinya tidak ada masalah dari istrinya, minimal istrinya tidak termasuk hal

12 Giorgio Di Lorenzo, Hypersexuality: the controversial mismatch of the psychiatric diagnosis, Journal of Psycopathology, 2018:24, hlm. 188

13 Ibid.

14 Isti Rahmadhani, MENTAL ILLNESS: Definisi Gangguan Umum Tanda-Tanda Awal dan Cara Menanganinya, https://www.researchgate.net/profile/Isti Rahmadhani, diakses tanggal 7 September 2020 pukul 11.49 
yang di syaratkan Undang-Undang Perkawinan. Alasannya suami tidak dapat mengontrol keinginan berhubungan seksual yang ada pada dirinya. Kemudian hakim mengabulkan permohonan suami, artinya hakim mengizinkan suami untuk poligami. Ratio decidendi hakim sampai mengabulkan adalah, karena istri tidak dapat menjalanan kewajibannya sebagai seorang istri. Dari alur ini tidak dapat dilihat benang merahnya. Masalahnya ada pada suami, tetapi yang dibebani tanggung jawab adalah istri. Permohonan dikabulkan dengan ratio decidendi seperti itu adalah stigma bagi istri bahwa istri tidak dapat menjalankan kewajiban sebagai seorang istri. Hal yang menjadi perhatian adalah ratio decidendi dari putusan tersebut yang kemudian mengarah ke diskriminasi.

Terjadi pembedaan antara posisi laki-laki dan perempuan dalam hukum. Jika suami yang mengidap gangguan mental yaitu hiperseksual maka istri yang harus menanggungnya. Tidak hanya rasa sakit fisik, tapi juga batin yaitu diberikan stigma tidak menjalankan kewajibannya sebagai istri oleh hukum, dengan pengadilan memberi izin pada suami untuk poligami. Walaupun syarat izin tertulis dari istri telah dipenuhi. Dapat disimpulkan bahwa dari putusan pengadilan ini solusi untuk suami hiperseksual adalah poligami. Hal ini tidak sesuai dengan keadilan gender dalam Islam, karena terjadi pembedaan posisi antara laki-laki dan perempuan. Islam memang mengenal perbedaan, posisi perempuan dan laki-laki berbeda dalam Islam, tetapi bukan pembedaan. Sehingga yang menjadi perhatian adalah ratio decidendi hakim dengan mengkategorikan hal seperti ini kedalam rumusan pasal 4 ayat (2) huruf a yaitu istri tidak dapat menjalankan kewajibannya sebagai istri, bukan praktek poligaminya.

\section{Kajian Mengenai Gender}

Gender dalam bahasa Inggris diterjemahkan berarti kelamin. Kelamin dalam Kamus Besar Bahasa Indonesia dapat diartikan sebagai sifat jasmani atau rohami yang membedakan dua makhluk sebagai betina dan jantan atau wanita dan pria. ${ }^{15}$ Menurut Nazaruddin Umar gender diartikan sebagai perbedaan antara laki-laki dan perempuan dari segi sosio kultural bukan secara biologis. ${ }^{16}$ Presiden Abdurrahman Wahid melalui instruksinya yaitu Inpres No. 9 Tahun 2000 tentang Pengarusutamaan Gender dalam Pembangunan Nasional mendukung pengarusutamaan gender dalam pembanguan nasional. Pada Inpres tersebut Presiden menginstruksikan pada Menteri, Kepala Lembaga Pemerintahan Non Departemen, Pimpinan Kesekretariatan Lembaga Tertinggi/ Tinggi Negara, Panglima Tentara Nasional Indonesia, Kepala Kepolisian Republik Indonesia, Jaksa Agung Republik Indonesia, Gubernur, Bupati/ Walikota untuk melaksanakan pengarusutamaan gender guna terselenggaranya perencanaan, penyusunan, pelaksanaan, pemantauan,dan evaluasi atas kebijakan dan program pembangunan nasional yang berperspektif gender sesuai dengan bidang tugas dan fungsi, serta kewenangan masing-masing.

Inpres tersebut memaknai gender adalah konsep yang mengacu pada peran-peran dan tanggung jawab laki-laki dan perempuan yang terjadi akibat dari dan dapat berubah oleh keadaan sosial dan budaya masyarakat. Sedangkan yang dimaksud dengan pengarus utamaan gender adalah strategi yang dibangun untuk mengintegrasikan gender menjadi satu dimensi integral terdiri dari perencanaan, penyusunan, pelaksanaan, pemantauan dan evaluasi atas kebijakan dan program pembangunan nasional. Dalam Inpres ini juga menjelaskan keadilan serta kesetaraan gender. Keadilan gender menurut Inpres ini adalah suatu proses untuk menjadi adil terhadap laki-laki dan perempuan. Kesetraan

15 Kelamin/ke-la-min/, Kamus Besar Bahasa Indonesia versi daring, http://kbbi.web.id/kelamin diakses tanggal 10 Agustus 2020 pukul 19.30

${ }^{16}$ Rusdi Zubeir, Gender Dalam Perspektif Islam, An Nisa'a, Vol. 7, No. 2, Desember 2012, hlm. 106 
gender adalah kesamaan kondisi bagi laki-laki dan perempuan untuk memperoleh kesempatan dan hak-haknya sebagai manusia, agar mampu berperan dalam kegiatan politik, ekonomi, sosial, budaya, pertahanan, dan keamanan nasional dan kesamaan dalam menikmati hasil pembangunan tersebut. ${ }^{17}$

Karena gender merupakan konsep yang mengacu pada peran-peran dan tanggung jawab laki-laki dan perempuan yang terjadi akibat dari dan dapat berubah oleh keadaan sosial dan budaya masyarakat. Peran-peran dalam masyarakat yang dimaksud adalah: ${ }^{18}$

\section{a. Peran Gender}

Peran laki-laki dan perempuan dalam lingkungan, budaya serta struktur masyarakat, sehingga akan terbentuk persepsi, bahwa itulah peran laki-laki dan perempuan di masayarakat.

b. Peran Produktif

Peran laki-laki dan perempuan yang diukur dari menghasilkan sesuatu. Sesuatu disini yang bernilai ekonomi. Bisa juga dianggap peran dalam pekerjaan. Nah kemudian terbentuk di masyarakat bahwa seharusnya yang mencari nafkah dalam arti bekerja adalah laki-laki. Sehingga perempuan dianggap tidak mempunyai peran produktif. Padahal perempuan bisa juga mempunyai peran produktif tanpa harus meninggalkan rumah, dalam arti dapat bekerja dari rumah.

c. Peran Reproduktif

Peran ini yang dianggap sebagai peran perempuan, kebalikan dari peran produktif tadi. Perempuan dianggap tidak memiliki peran produktif, sedangkan laki-laki dianggap tidak memiliki peran reproduktif. Mengapa perempuan, karena perempuan yang memiliki rahim, yang melahirkan, kemudian yang harus merawat, sehingga perempuan dibebani tanggung jawab ini. Padahal sesungguhnya laki-laki pun memiliki peran reproduktif, bersinergi dengan perempuan dalam hal bereproduksi.

d. Peran Sosial (Kemasyarakatan)

Peran ini merupakan aktivitas yang diperlukan untuk menjalankan organisasi di masyarakat. Memimpin sesuatu di masyarakat, misalnya di lingkungan tempat tinggalnya.

Sehingga dapat diartikan bahwa gender adalah sesuatu yang dibentuk oleh masyarakat itu sendiri dalam memaknai perbedaan laki-laki dan perempuan, bukan perbedaan secara kodrat. Karena jika secara kodrat, secara bilologis memang berbeda, dan tidak ada masalah dengan itu. Karena laki-laki dan perempuan secara fisik dilahirkan berbeda, secara biologis mempunyai fungsi yang tidak sama. Bentuk fisik penampakan laki-laki dan perempuan terlihat jelas berbeda, begitu pula laki-laki tidak dapat melahirkan keturunan karena tidak memiliki rahim. Tetapi sebaliknya perempuan tidak dapat mengandung dengan sendirinya jika tidak ada andil laki-laki. Maka secara kodrati pula laki-laki dan perempuan terlahir untuk saling bersinergi, saling bekerja sama dan saling melengkapi untuk dapat mencapai tujuan yang sama yaitu manusia yang bermanfaat bagi sekitarnya. Sehingga meskipun dilahirkan berbeda antara laki-laki dan perempuan, tidak ada pembedaan. Pembedaan bahwa perempuan dianggap sebagai makhluk yang tidak bisa

17 Convention Watch, Pusat Kajian Wanita dan Gender, Universitas Indonesia dan Yayasan Obor Indonesia, Hak Azasi Peremuan-Instrumen Hukum Untuk Mewujudkan Keadilan Gender, Yayasan Obor Indonesia, Jakarta, 2007, hlm. 313

18 Kamla Bhasin, Understanding Gender diambil dari http://sc.syekhnurjati.ac.id/esscamp/risetmhs/BAB214111410046.pdf, diakses tanggal 7 September 2020 pukul 11.38 
apa-apa, sebagai makhluk yang tidak boleh berkehendak, tidak bisa mengambil peran apa-apa di masyarakat. Pembedaan yang ada di masyarakat ini yang kemudian melahirkan ketidakadilan gender.

Menurut Mansour Fakih dalam bukunya Analisis Gender dan Trasformasi Sosial, ketidakadilan gender ini berbentuk: ${ }^{19}$

1. Terjadi marginalisasi (terutama pemiskinan ekonomi) terhadap perempuan.

2. Terjadinya subordinasi pada salah satu jenis kelamin, umumnya kepada kaum perempuan.

3. Pelabelan negatif (strereotype) terhadap jenis kelamin tertentu, yang berakibat diskriminasi dan berujung ketidakadilan.

4. Kekerasan terhadap jenis kelamin tertentu, umumnya terhadap perempuan.

5. Beban kerja lebih panjang dan lebih banyak (double burden).

Semua manifes ketidakadilan gender di atas saling terkait dan tersosialisasi dengan kuat sehingga menjadi konstruksi sosial dan akhirnya dipahami menjadi kodrat.

\section{Kajian Mengenai Gender dan Poligami}

Bicara mengenai putusan pengadilan di atas jelas tidak lepas dari bicara tentang poligami atau beristri lebih dari seorang. Karena obyek dari putusan tersebut adalah permohonan poligami. Tidak mempersoalkan poligaminya, tidak ada masalah jika seseorang menginginkan berpoligami, karena hal tersebut merupakan hukum Allah SWT. Tercantum di Alquran dan hukumnya dibolehkan asalkan dapat memenuhi syarat adil. Undang-Undang Perkawinan pun berusaha mengatur selaras dengan Alquran, mengatur dengan ketat bagi suami yang ingin berpoligami, demi perlindungan hukum. Walaupun ada beberapa hal yang tidak pas digunakan sebagai syarat dalam pasal alasan berpoligami, karena menyudutkan wanita. Tetapi di sisi lain itupun digunakan sebagai bentuk perlindungan hukum.

Tidak juga kemudian dimaknai poligami adalah praktek ketidakadilan gender. Tidak ada yang salah juga dengan praktek poligami ketika itu dilakukan sesuai hukum Allah SWT. Menjadi masalah adalah ratio decidendi hakim pada putusan tersebut ketika mengabulkan permohonan poligami. Ratio decidendi hakim tersebut mengarah pada ketidakadilan gender, menyebabkan pelabelan negatif terhadap perempuan dalam hal ini istri. Masalahnya putusan hakim adalah hukum. Sehingga ada pelabelan negatif pada istri oleh hukum. Istri dianggap tidak menjalankan kewajibannya sebagai istri, karena suaminya hiperseksual, sedangkan istri sudah melakukan kewajibannya hanya tidak mampu jika terus menerus dalam kondisi seperti itu. Suami yang memiliki masalah, diberikan solusi oleh hakim yaitu poligami dengan melabeli negatif istri tidak menjalankan kewajibannya sebagai istri.

\section{Kajian Mengenai Adil Dalam Islam}

Adil atau keadilan disebutkan sangat banyak dalam Alquran, baik melalui kata 'adl, qist maupun mizan. Hal itu menunjukan Allah SWT sangat mementingkan keadilan. Karena tujuan Islam adalah rahmatan lil 'alamin, sebagai pembawa rahmat bagi alam semesta. Artinya lagi dalam Islam keadilan menjadi hal yang sangat penting. Dalam Islam diatur agar manusia sebagai khalifah di bumi harus berlaku adil. Contoh dalam surat AnNisa' ayat 135 Allah memerintahkan manusia untuk menjadi penegak keadilan dan dilarang berpihak mengikuti hawa nafsu. Juga dalam surat Al-Maidah ayat 8 Allah

${ }^{19}$ Nur Kholis, Jumaiyah, Wahidullah, Poligami dan Ketidakadilan Gender Dalam Undang-Undang Perkawinan Indonesia, Al Ahkam Volume 27, Nomor 2, Oktober 2017, hlm. 199 
memerintahkan orang beriman untuk menjadi penegak keadilan ketika menjadi saksi, bahwa kebencian terhadap suatu kaum tidak boleh mejadi dasar berbuat tidak adil. Pada Alquran kata adil dapat bermakna: ${ }^{20}$

\section{Sama}

Sama yang dimaksud di dalam Alquran adalah persamaan hak, juga tidak ada pembedaan terhadap setiap individu. Ada perbedaan tetapi bukan pembedaan. Beberapa contoh adil yang bermakna persamaan hak, pada surat An-Nisa' ayat 3 tentu saja ini ayat tentang bolehnya beristri lebih dari 1 orang, justru dalam ayat ini diberikan keadilan karena Allah membatasi hanya boleh sampai 4 orang saja. Ayat ini memerintahkan suami untuk berlaku adil, memperhatikan persamaan hak diantara istri-istrinya, serta mengandung peringatan atau ancaman Allah jika tidak berlaku adil. Pada ayat 58 nya juga diperintahkan berlaku adil dalam menetapkan hukum diantara manusia. Artinya hakim ketika menetapkan hukum bagi manusia harus adil. Pada surat An-Nahl ayat 90 Allah memerintahkan berbuat adil dan berbuat kebajikan dan memberi bantuan kepada kerabat.

2. Seimbang

Adil dapat dimaknai juga dengan seimbang. Allah menciptakan dan mengelola segala sesuatu dengan seimbang, sesuai dengan kadar, ukuran, juga waktu tertentu. Termasuk menciptakan tubuh manusia dengan seimbang, tidak mungkin tubuh manusia diciptakan berlebih satu dengan lainnya, karena memiliki fungsinya masing-masing. Seperti yang diatur dalam surat Al-Infitar ayat 7. Kemudian juga tentang alam semesta diciptakan oleh Allah dengan keseimbangan, berjalan harmoni, ada siang-malam, panas-dingin, kemarau-hujan. Begitu juga dalam surat Al-Maidah ayat 95, Allah mengajarkan keseimbangan melalui sanksi atas pelanggaran yang dilakukan. Orang yang berihram atau sedang berhaji dilarang berburu hewan buruan ketika dilanggar maka sanksinya adalah mengganti hewan yang sepadan dengan hewan yang diburunya, atau dengan membayar tebusan dengan memberi makan orang miskin, atau dengan berpuasa, seimbang dengan makanan yang dikeluarkan.

3. Memperhatikan dan memberikan hak tiap individu

Adil ini dapat dimaknai menempatkan sesuatu sesuai porsinya atau pada tempatnya. Allah memerintahkan manusia untuk berbuat adil sekalipun kepada kerabat dalam surat Al-An'am ayat 152.

4. Kewajaran dan Kepatutan

Adil dapat dimaknai dengan sesuatu yang wajar dan patut. Sehingga sesuatu bisa jadi tidak sama persis tetapi substansinya sama sesuai dengan kewajaran dan kepatutan.

\section{Kajian Mengenai Keadilan Gender Dalam Islam}

Keadilan gender dalam Islam dapat dimaknai berlaku adil dan tidak membedakan jenis kelamin tertentu dalam hal fitrahnya sebagai manusia. Tidak membedakan apa itu laki-laki apa itu perempuan sebagai khalifah di bumi. Dapat dibuktikan jika melihat kalam-kalam Allah SWT dalam Alquran.

1. Islam tidak mengenal pembedaan antara laki-laki dan perempuan dalam hal keadilan. Jika setara yang dimaksud perempuan sama dengan laki-laki, jelas tidak.

${ }^{20}$ Qurrotul Ainiyah, Keadilan Gender Dalam Islam - Konvensi PBB Dalam Perspektif Mazhab Shafi'I, Intrans Publishing, Malang, 2015, hlm. 20 
Dari segi fisik berbeda, dari segi tanggung jawab juga berbeda, kewajiban pun berbeda satu sama lain. Tetapi sebagai makhluk ciptaan Allah dan khalifah di bumi, laki-laki dan perempuan mempunyai kedudukan yang sama. Laki-laki dan perempuan layak diperlakukan sama, sama-sama layak diberi keadilan. Tidak ada pembedaaan. Hal ini terbukti dalam surat Al Isra ayat 70, yang dapat disimpulkan Allah memuliakan anak cucu Adam yaitu manusia, diciptakan dengan kelebihan yaitu berupa akal, juga diberikan rezeki yang baik.

2. Islam tidak mengenal perbedaan perlakuan antara laki-laki dan perempuan, semua sama di mata Allah yang membedakan adalah ketaqwaan. Ini merupakan kesimpulan dari surat Al Hujurat ayat 13. Allah sama sekali tidak membedakan antara laki-laki dan perempuan, miskin kaya, semua sama dihadapan Allah SWT. Allah SWT hanya melihat ketaqwaan masing-masing, hanya itu penilaian Allah SWT.

3. Perbedaan tentang tanggung jawab yaitu dilebihkan sedikit untuk laki-laki, karena laki-laki bertanggung jawab atas perempuan. Perempuan sama sekai tidak dibebani tanggungjawab sebagaimana lak-laki. Laki-laki adalah pelindung perempuan, pemimpin perempuan yaitu dalam surat An Nisa ayat 34. Tetapi sebagai pemimpin disini bukan dalam arti sewenang-wenang. Bukan juga dapat memperlakukan wanita seenaknya.

4. Allah bahkan menjamin hak perempuan pada surat Al Baqarah ayat 228, dikatakan "dan mereka perempuan memiliki hak yang seimbang dengan kewajibannya." Hal ini senada dengan surat An Nisa' ayat 34

5. Allah SWT tidak akan menyia-nyiakan amal baik laki-laki maupun perempuan. Semua akan mendapat pahala yang sama. Seperti yang disebutkan dalam surat Al Imran ayat 195. Sungguh Allah tidak membedakan amal baik laki-laki atau perempuan, karena laiki-laki berasal dari lakilaki dan perempuan, begitu juga sebaliknya, sehingga keduanya sama sebagai manusia. Tidak ada kelebihan antara satu dengan lainnya dalam hal penilaian iman dan amalnya.

6. Allah SWT akan memasukkan ke surga bagi siapapun yang mengerjakan amal kebajikan. Surat An-Nisa' ayat 124 menyebutkan Allah akan memasukkan ke surga bagi siapapun yang mengerjakan amal kebajikan baiklaki-laki maupun perempuan. Ayat ini senada dengan surat Al Imran ayat 195. Bentuk penegasan Allah terhadap tidak adanya pembedaan antara laki-laki dan perempuan.

7. Allah memberikan rahmat pada siapapun yang beriman juga menjanjikan surga bagi orang mukmin. Ayat ini ada dalam surat At-Taubah ayat 71-72. Bahwa Allah akan memberikan rahmat dan menjanjikan surga bagi orang yang beriman baik laki-laki maupun perempuan.

8. Allah akan memberikan ampunan dan pahala yang besar bagi laki-laki dan perempuan yang berada dalam ketaatannya. Hal ini ada di surat Al Ahzab ayat 35. Allah tidak membedakan laki-laki maupun perempuan yang tetap berada dalam ketaatannya maka Allah akan berikan ampunan juga pahala.

9. Tidak hanya soal pahala Allah berikan kesetaraan bagi laki-laki maupun perempuan tetapi juga soal hukuman. Allah menghukum perempuan dengan hukuman yang sama dengan laki-laki. Seperti pada surat Al Maidah ayat 38. Allah menghukum potong tangan bagi laki-laki dan perempuan yang mencuri sebagai siksaan dari Allah.

Selain ayat Allah di atas sebagai bukti secara normatif Alquran mendudukkan perempuan setara dengan laki-laki. Islam mengenal konsep keadilan gender juga ada 
dalam sumber hukum Islam yang kedua yaitu Sunnah Rasulullah. Nabi Muhammad bersabda "Aku wasiatkan kepada kalian untuk berbuat baik kepada para wanita" (HR. Muslim). ${ }^{21}$ Juga "orang mukmin yang paling sempurna imannya adalah mereka yang memiliki akhlak mulia dan sebaik-baik kalian adalah mereka yang berperilaku baik terhadap perempuan-perempuan mereka" (HR. At-Tirmidzi). Hal tersebut hanya segelintir contoh sabda Rasulullah untuk memuliakan wanita. Sehingga dalam kaitannya dengan perbuatan yang membedakan antara laki-laki dan perempuan jelas bertentangan dengan ayat Allah di atas. Begitu pula dengan ratio decidendi hakim di atas, merupakan upaya pembedaan antara laki-laki dan perempuan, serta memberikan label negatif terhadap perempuan. Sehingga tidak sesuai dengan prinsip keadilan gender dalam Islam. Sedangkan putusan hakim adalah hukum, sehingga hukum tersebut mendiskriminasi posisi perempuan. Kontra dengan apa yang secara normatif tertulis dalam Alquran tentang posisi perempuan serta bagaimana memperlakukan perempuan.

\section{Kajian Mengenai Keadilan Pada Pernikahan}

Pernikahan dalam Islam merupakan sesuatu yang luhur karena merupakan ibadah, menjalankan perintah Allah. Pernikahan merupakan miitsaaqan ghaliidhan, akad yang sangat kuat karena sebagai pasangan suami istri sedang berjanji di hadapan Allah akan saling memperlakukan dengan baik dan membentuk keluarga yang baik yang bertujuan pada Allah Ta'ala. Pada surat An-Nisa' ayat 21 dapat ditemukan kata miitsaaqan ghaliidhan, yang kemudian diterjemahkan sebagai perjanjian yang sangat kuat antara suami dan istri, yang kemudian dimaknai istri yang mengambil perjanjian itu terhadap suami. Kemudian pada surat Al-Baqarah ayat 231 ditegaskan pula Allah mengambil perjanjian dari suami yaitu:

Apabila kamu mentalak isteri-isterimu, lalu mereka mendekati akhir iddahnya, maka rujukilah mereka dengan cara yang ma'ruf, atau ceraikanlah mereka dengan cara yang ma'ruf (pula). Janganlah kamu rujuki mereka untuk memberi kemudharatan, karena dengan demikian kamu menganiaya mereka. Barangsiapa berbuat demikian, maka sungguh ia telah berbuat zalim terhadap dirinya sendiri. Janganlah kamu jadikan hukumhukum Allah permainan, dan ingatlah nikmat Allah padamu, dan apa yang telah diturunkan Allah kepadamu yaitu Al Kitab dan Al Hikmah (As Sunnah). Allah memberi pengajaran kepadamu dengan apa yang diturunkan-Nya itu. Dan bertakwalah kepada Allah serta ketahuilah bahwasanya Allah Maha Mengetahui segala sesuatu. ${ }^{22}$

Ayat di atas dapat dimaknai laki-laki berbuat tidak baik pada wanita dikategorikan perbuatan dzalim dan mengundang murka Allah. Ayat ini pun mendukung ayat-ayat yang tersebut di atas mengenai keadilan gender, menegaskan analisis di atas mengenai lakilaki yang dilebihkan sedikit dari wanita karena tanggung jawabnya. Dilebihkan bukan untuk sewenang-wenang.

Dari ayat-ayat di atas dapat disimpulkan ketika akad itu telah terjadi maka segala akibat hukum melekat. Suami harus memperlakukan istri dengan cara yang ma'ruf (baik dan patut), begitu juga sebaliknya. Allah melarang suami menyusahkan istri, berbuat sewenang-wenang dan berbuat dzalim. Dalam kehidupan perkawinan harus saling memperlakukan dengan santun. Bahkan ketika perceraian terjadi sekalipun Allah tetap memerintahkan laki-laki memperlakukan istri dengan santun. Bukti Allah memuliakan

${ }^{21}$ Kasmawati, Gender Dalam Perspektif Islam, Sipakalebbi', Volume 1 Nomor 1 Mei 2013, hlm.67

22 Terjemahan surat Al Baqarah ayat 231, https://tafsirweb.com/920-quran-surat-al-baqarahayat-231.html, diakses tanggal 18 Agustus 2020, pukul 20.00 
perempuan. Sehingga sesungguhnya pernikahan bukan transaksi hawa nafsu. Tidak dapat dipungkiri nafsu adalah karunia Allah. Allah memberikan nafsu untuk berhubungan seksual, nafsu memiliki, nafsu terhadap harta, tetapi poin pentingnya manusia diberi akal untk mengendalikan semua itu. Sehingga esensi dari perkawinan bukan alat untuk menyalurkan dan memuaskan nafsu seksual. Relasi dengan ratio decidendi hakim di atas, istri digunakan sebagai batu pijakan untuk mencapai penyaluran dan pemuasan nafsu semata. Karena begitu suami yang menpunyai gangguan kejiwaan hiperseksual tidak merasa puas dengan istrinya dan mengajukan permohonan poligami dan dikabulkan oleh hakim, maka itu sebuah solusi yang diberikan hakim untuk memuaskan dan menyalurkan nafsu seksualnya. Begitu suami merasa tidak puas lagi maka ia akan mengajukan permohonan poligami lagi, dikabulkan lagi dengan ratio decidendi yang sama oleh hakim, dan begitu seterusnya berulang. Ini kemudian yang disebut diskriminasi terhadap perempuan. Manusia berTuhan dan berakal tidak hanya berpikiran pada penyaluran keinginan manusia saja, tapi penghambaan kepada Allah, sebagaimana tujuan perkawinan Islam.

\section{PENUTUP}

Putusan pengadilan yang mengabulkan poligami dengan ratio decidendi hakim istri tidak dapat melakukan kewajibannya sebagai seorang istri merupakan hal yang tidak sesuai dengan keadilan gender terutama dalam Islam. Melalui ratio decidendi tersebut hukum membeda-bedakan posisi perempuan dengan laki-laki. Melabeli negatif perempuan untuk hal yang tidak dilakukannya atau hal yang bukan kesalahannya. Hal tersebut bertentangan dengan konsep keadilan gender dalam Islam yang tidak membedakan laki-laki dengan perempuan dalam fitrahnya sebagai khalifah di bumi. Hakim semestinya arif dan bijaksana dalam membuat ratio decidendi, sehingga memberikan keadilan bagi semua pihak. Tidak perlu memaksakan harus mengabulkan jika memang tidak layak untuk dikabulkan. Juga tidak perlu memaksakan harus memasukkan atau mengkategorikan pada sesuatu yang tidak semestinya, jika ingin mengabulkan. Karena hakim diberi keleluasaan untuk menggali hukum bahkan menemukan hukum jika memang harus demi keadilan.

\section{DAFTAR PUSTAKA}

\section{Buku}

Ainiyah, Qurrotul. 2015. Keadilan Gender Dalam Islam - Konvensi PBB Dalam Perspektif Mazhab Shafi'I. Malang: Intrans Publishing.

Marzuki, Peter Mahmud. 2005. Penelitian Hukum. Jakarta: Kencana Prenada Group.

Soejono dan Abdurahman, H. 2003. Metode Penelitian Hukum. Jakarta: Rineka Cipta.

Sulistyarini. 2020. Kesesuaian Alasan Suami hiperseksual Dalam Permohonan Izin Poligami Dengan Pasal 4 ayat (2) huruf a Undang-Undang Nomor 1 Tahun 1974 tentang Perkawinan. Skripsi. Fakultas Hukum Universitas Brawijaya.

Watch, Convention, Pusat Kajian Wanita dan Gender, Universitas Indonesia dan Yayasan Obor Indonesia, 2007. Hak Azasi Peremuan-InstrumenHukum Untuk Mewujudkan Keadilan Gender. Jakarta: Yayasan Obor Indonesia.

\section{Artikel Jurnal lewat website}


Di Lorenzo, Giorgio. Ciocca, G. Hypersexuality: The controversial mismatch of the psychiatric diagnosis. Diambil September, 7, 2020. Dari https://www.researchgate.net/profile/Giorgio Di Lorenzo/publicati $\mathrm{n} / 328042092$

Kasmawati. 2013. Gender Dalam Perspektif Islam. Sipakalebbi', 1 (1), 55-67. Diambil Juli, 27, 2020. Dari https://media.neliti.com/media/publications/221501gender-dalam persfektif-islam.pdf.

Rahmadhani, Isti. 2020. MENTAL ILLNESS Definisi Gangguan Umum Tanda Tanda Awal dan Cara Menanganinya. Diambil September, 7, 2020. Dari https://www.researchgate.net/profile/Isti_Rahmadhani/publication 338448901

Zubeir, Rusdi. 2012. Gender Dalam Perspektif Islam. An Nisa'a, (7) 2, 103-118. Diambil Juli, 27, $2020 . \quad$ Dari https://media.neliti.com/media/publications/56929-ID-gender dalamperspektif-islam.pdf.

\section{Artikel Jurnal (DOI)}

Kholis, Nur, Jumaiyah, Wahidullah. 2017. Poligami dan Ketidakadilan Gender Dalam Undang-Undang Perkawinan Indonesia. Al Ahkam, (27) 2, 195- 212.

http://dx.doi.org/10.21580/ahkam.2017.27.2.1971

\section{Website}

Bhasin, Kamla. Understanding Gender. Diambil September 7, 2020 pukul 11.38. Dari http://sc.syekhnurjati.ac.id/esscamp/risetmhs/BAB214111410 46.pdf

Kelamin/ke-la-min/. 2012-2019. Kamus Besar Bahasa Indonesia versi daring. Diambil Agustus 10, 2020. Dari http://kbbi.web.id/kelamin.

Terjemahan surat Al Baqarah ayat 231. 2020. Diambil Agustus 18, 2020. Dari https://tafsirweb.com/920-quran-surat-al-baqarah-ayat-231.html.

\section{Peraturan Perundang-undangan}

Undang-Undang Nomor 1 Tahun 1974 tentang Perkawinan. Lembaran Negara Tahun 1974 Nomor 1. Tambahan Lembaran Negara Nomor 3019.

Peraturan Pemerintah Nomor 9 Tahun 1975 tentang Pelaksanaan Undang-Undang Nomor 1 Tahun 1974 tentang Perkawinan. Lembaran Negara Tahun 1975 Nomor 12 .

Instruksi Presiden Republik Indonesia Nomor 1 Tahun 1991 tentang Kompilasi Hukum Islam

\section{Putusan Pengadilan}

Putusan Nomor 2670/Pdt.G/2012/PA/Lmg.

Putusan Nomor 905/Pdt.G/2012/PA/JB.

Putusan Nomor 2593/Pdt.G/2017/PA.Jbg.

Putusan Nomor 0616/Pdt.G/2015/PA.Pw 